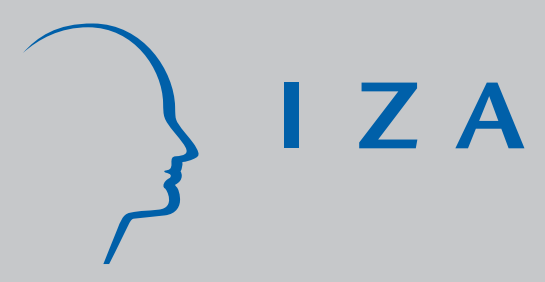

IZADP No. 2684

How Many Hours Do You Have to Work to Be Integrated? Full Time and Part Time Employment of

Native and Ethnic Minority Women in the Netherlands

Pieter Bevelander

Sandra Groeneveld

March 2007 


\title{
How Many Hours Do You Have to Work to Be Integrated? Full Time and Part Time Employment of Native and Ethnic Minority Women in the Netherlands
}

\author{
Pieter Bevelander \\ IMER, Malmö University \\ and IZA
}

Sandra Groeneveld

Erasmus University Rotterdam

Discussion Paper No. 2684

March 2007

\author{
IZA \\ P.O. Box 7240 \\ 53072 Bonn \\ Germany \\ Phone: +49-228-3894-0 \\ Fax: +49-228-3894-180 \\ E-mail: iza@iza.org
}

\begin{abstract}
Any opinions expressed here are those of the author(s) and not those of the institute. Research disseminated by IZA may include views on policy, but the institute itself takes no institutional policy positions.

The Institute for the Study of Labor (IZA) in Bonn is a local and virtual international research center and a place of communication between science, politics and business. IZA is an independent nonprofit company supported by Deutsche Post World Net. The center is associated with the University of Bonn and offers a stimulating research environment through its research networks, research support, and visitors and doctoral programs. IZA engages in (i) original and internationally competitive research in all fields of labor economics, (ii) development of policy concepts, and (iii) dissemination of research results and concepts to the interested public.
\end{abstract}

IZA Discussion Papers often represent preliminary work and are circulated to encourage discussion. Citation of such a paper should account for its provisional character. A revised version may be available directly from the author. 


\section{ABSTRACT \\ How Many Hours Do You Have to Work to Be Integrated? Full Time and Part Time Employment of Native and Ethnic Minority Women in the Netherlands}

Labor market participation is a central factor in the economic integration of migrants in their host country. Labor market integration of ethnic minority women is of special interest, as they may experience a double disadvantage: both as a woman and as a migrant. Since the late nineties this presumed double disadvantage has become more and more the focus of both Dutch integration and Dutch emancipation policy. To test several assumptions underlying Dutch policy this paper focuses on the employment patterns of ethnic minority and native women in the Netherlands. In particular, we analyze to what extent labor market participation of different groups of women and the hours they work are influenced by human capital and household characteristics. Our results show some remarkable differences in employment patterns between native Dutch and ethnic minority women. Controlling for educational level, partnership and the presence of children, native Dutch women are working more often in part time jobs than Mediterranean and Caribbean women. For all women the educational level is an important determinant of employment and the number of hours worked. Whereas the number of children influences both the employment decision and the number of hours worked of native Dutch women, for Mediterranean and Caribbean women there is only an effect of the number of children on the odds of having a full time job.

JEL Classification: F22, J22, J61

Keywords: employment integration, ethnic minority women, hours worked

Corresponding author:

Pieter Bevelander

IMER

Malmö University

20506 Malmö

Sweden

E-mail: pieter.bevelander@imer.mah.se 


\section{$1 \quad$ Introduction}

In 2005 the Dutch central government initiated a publicity campaign that was aimed at enhancing the participation of ethnic minority women in local community activities. The campaign was titled 'At home in the Netherlands. Participate!' making clear that participation is central to integration. Participation, both labor market participation and social participation, is a core element of the policy that is aimed at the integration and emancipation of ethnic minority women in the Netherlands.

During the last years, in the public and political debate the integration and emancipation have become two sides of the same coin. The integration debate, and in particular the integration policy has changed from multiculturalism towards assimilation and from stressing structural integration to a larger attention to culture. In this context, culture is seen as a stable entity of norms and values and moreover used as an important explanation for the falling behind of ethnic minorities in structural integration like education, work and income. Besides, it is especially the Islamic culture, placed against the Dutch, which has become in focus. The stress on culture in the integration debate is followed by a gradual focus on the position of women. These are seen as both victims of their culture and responsible for their emancipation. The 'gendering' of the integration debate in the Netherlands goes along with a larger emphasis on women from ethnic minorities in the emancipation debate and policy. Assumed in this is that the emancipation of Dutch women is as good as accomplished. They are seen as the norm against which the integration of ethnic minority (read: Muslim) women strongly stands out.

The goals of the emancipation policy are various and vary from labor market participation and economic independency to decreasing of the violence against girls and women. Only for labor participation and economic independency of women the goals are operationalized. For the year 2010 the target is that 65 percent of the women is participating on the labor market and that 60 percent of the women in the Netherlands is economically independent. Economically independent is here defined as earning at least 70 percent of the minimum wage by paid work. Besides, there is the ambition that men and women have a more equal share in paid and unpaid work, i.e. household tasks. It is 
expected that this in turn has a decreasing influence of family formation on the labor market participation of women.

In previous studies we found increasing employment levels for both native Dutch and ethnic minority women in almost all age groups, with native Dutch and Caribbean women showing the strongest employment integration and Mediterranean women the weakest. The presence of children has a negative influence on the probability to be employed for all groups in both 1991 and 2002, but its effect is smaller for the year 2002. This result indicates that the attachment of women to the labor market becomes stronger and the influence of motherhood indeed becomes smaller over time.

Following the policy direction of the last years several other studies have focused on the labor market participation of native and ethnic minority women in the Netherlands (Hooghiemstra \& Merens, 1999; Groeneveld, Marx \& Merens, 2004; Van Tubergen \& Maas, 2004; Keuzenkamp \& Merens, 2006). However, these studies pay almost no attention to the number of hours worked by women. The strong importance of part time work in the Dutch labor market as well as the central place these part time jobs have in the perception on emancipation in the Netherlands (freedom of choice) makes it interesting to study the differences in labor force participation and hours worked between native and ethnic minority women and in particular to analyze to what extent the number of hours worked in paid employment is influenced and by factors connected to family formation and human capital characteristics. Hence, the focus of this paper is on the following questions:

- To what extent are there differences in labor market attachment (both employment and hours worked) between native and ethnic minority women in the Netherlands?

- To what extent are differences in employment and hours worked of ethnic minority and native women explained by family formation and human capital characteristics?

The outline of the paper is as follows. First, the Dutch context is described in the next section. Then some theoretical considerations and previous research are discussed in 
section 3. Section 4 describes the data, methods and variables used and in section 5 the results are presented. In section 6 we conclude and discuss our findings.

\section{Context: the Netherlands}

This section gives some background information on the Netherlands. Both demographic and labor market characteristics are described. Most figures refer to the year 2002 unless otherwise is stated. In addition, the relevant Dutch policy context is briefly discussed.

\section{Demographic characteristics}

In 2002 approximately two third of the migrants and their descendents in the Netherlands, are from the Mediterranean (Turkey and Morocco) and the Caribbean (Suriname and Dutch Antilles) region. These four ethnic groups add up to more than one million persons on a total population of sixteen million people (table 1). The analyses in the paper are restricted to Turkish, Moroccan, Surinamese and Antillean women and their families, comprising the four largest ethnic minority groups in the Netherlands in 2002.

Table 1 Native and ethnic minority population in the Netherlands, 2002

\begin{tabular}{llll}
\hline & total $($ x 1,000) & \% 2nd generation & \% women \\
\hline Native Dutch & 13,140 & - & 51 \\
Turks & 331 & 44 & 48 \\
Moroccans & 284 & 44 & 47 \\
Surinamese & 315 & 41 & 53 \\
Antilleans & 125 & 34 & 51 \\
\hline
\end{tabular}

Source: Statline, Statistics Netherlands

The migrant population in the Netherlands is young compared to the native population. As a result their share in the total labor force is relatively high and continues to grow in the next decades. The average age of a woman having her first child as well as the number of children per woman, is still related, but with time to a lesser degree, to the

\footnotetext{
${ }^{1}$ First generation ethnic minorities are those who actually immigrated. Second generation ethnic minorities are those who are born in the Netherlands but have at least one foreign-born parent.
} 
labor force participation of women. This makes it interesting to take a look at the fertility rates. Fertility rates are rapidly changing in the Netherlands. Over time Dutch women become a mother at a later age and have less children than before. On average Dutch women become a mother at the age of 29. Turkish and Moroccan women, however, are having children in their early twenties. Whereas Moroccan, Surinamese and Antillean women from the younger age cohorts become a mother at a later age, young Turkish women are still having children at an early age. In addition, second generation women become a mother at a later age than first generation women. Besides, ethnic minority women have more children than the native Dutch, with Moroccan women having most children on average and Surinamese and Antillean women least. However, this difference is smaller for the younger age cohorts. All in all, fertility patterns of native Dutch and ethnic minority women are converging in the last decade (Van der Laan Bouma-Doff and Groeneveld, 2004; Keuzenkamp \& Merens, 2006).

Does having a partner or being married affects the labor force participation by women? To this question no unambiguous answer can be given. The general opinion is that in modern societies, partnership does not influence the labor force participation of women. This is probably the case when we examine participation rates of men and women, but when it comes to the number of hours worked in the paid labor market. Moreover, single parenthood could influence the possibilities to partake in the labor market. This makes that besides fertility also partnership has to be examined when it comes to study the labor force participation of native and ethnic minority women.

Cohabitation is rather common in the Netherlands. For both the native and the Caribbean the percentage of couples that are cohabiting is increasing. Of the Mediterranean, however, most couples are married. Most Turkish and Moroccan women are married to a man from the same ethnic group. Surinamese and Antillean women, however, are marrying native Dutch men more often (43 and 61 percent of the marriages respectively in the period 1997-2001). Besides, Surinamese and Antillean women are a single mother relatively often (Van der Laan Bouma-Doff and Groeneveld, 2004; Keuzenkamp \& Merens, 2006). 


\section{Female labor market participation}

The position of women on the Dutch labor market has improved significantly. Not only the female employment rate increased, but also their mean job level has increased strongly. Moreover, this upgrading is stronger than it is for men, implicating that differences in job level between men and women have diminished and more and more can be explained by differences in age, education and part time work.

Kalmijn and Luijkx (2003) analyzed retrospective life-history data in order to describe changes in women's employment careers in the Netherlands. As the probability of leaving the labor market has continuously declined in the period 1955-2000, their results also show that the probability of re-entering the labor market has continuously increased. Besides, the influence of life course stages on employment has become smaller over time. Marriage no longer leads to employment exits. Motherhood, however, still does. All in all, the attachment of women to the labor market has become stronger. Instead of entirely withdrawing from the labor market, women reduce their working hours when they become a mother (Vlasblom and Schippers, 2005). The majority of the (native) Dutch women are working part time. The single-male-breadwinner-model is replaced by the so-called 1.5-breadwinner-model with the man as the primary earner.

As the Netherlands has had joint-taxation rules until recently the partner with lower earnings is more or less encouraged to reduce working hours or leave employment. Earlier research suggests that this is a central institutional factor in understanding women's employment patterns in the Netherlands (Dingeldey, 2001). Also, day-care and other work-family arrangements have become more common only rather recently, especially compared to the Nordic countries. It is assumed that the availability of workfamily arrangements is an important determinant of women's labor market participation. In a recent study on mothers' labor market participation in the Netherlands Portegijs et al. (2006) however show that 'the availability and costs of formal childcare facilities play virtually no role in mothers' decisions on childcare and labor market participation.'

The Netherlands is known for their strong and prevailing motherhood ideology that is more and more reconciled with labor market participation. Part time employment with relatively short working hours now seems to be the norm for mothers (Anxo et al., 2006). Portegijs et al. (2006) conclude that 'views about employment and childcare are 
the main factors determining whether mothers are willing to work and whether they are prepared to use childcare facilities'.

\section{Policy context: emancipation and integration policy}

A central issue in the Dutch emancipation policy is the goal to increase labor market participation by women. In 201065 percent of the women should be in paid employment for more than twelve hours a week. Moreover, since 2001 special attention has been paid to ethnic minority women, as they show a participation rate that on average is (even) smaller than that of native Dutch women. It is increasing at a higher pace, however.

The emancipation policy has, however, contradictory objectives for women. Recognizing an aging population, on the one hand, labor market policies should aim at making it easier for women to work and/or to in increase the number of work hours in the labor market. On the other hand, it is stressed that women should feel 'free' to choose between paid work and care for family. One way to look at this contradictory policy aims are by former Minister De Geus (Christian Democratic Party), suggesting a focus on participation in general, in which social participation like voluntary work and paid work should be valued equally. Besides, especially Muslim women are targeted since they still have a considerable lower labor market attachment. As mentioned in the introduction, we see in the integration policy the backside of the medal: a large attention for women as the driving force behind integration, but at the same time suffering from the retarding integration of some ethnic groups, namely, the Turkish and even more the Moroccan with an Islamic background.

\section{$3 \quad$ Theoretical considerations}

The starting point of this paper is a simple human capital model, which links increased labor force participation and higher educational attainment of women to lower and postponed fertility. From a household perspective, the existence of a gender wage gap enhances the specialization of women into household and men into labor market production activities (Becker, 1981). 
The inverse relationship between fertility and women's employment predicted by human capital theory is repeatedly affirmed (see Budig, 2003 for an overview), but seldom studied for migrant women. In fact, findings have been dominantly US-based, with only a handful of research conducted in European countries. Here, the relationship remains unclear and is dependent on the model being tested (Bevelander, 2005; Andersson and Scott, 2004). In addition, the child effect on employment is highly context-bound and appears to vary with the country of origin (Bevelander and Groeneveld, 2006a). Moreover, only the decision to participate is analyzed without taking the number of hours worked into account.

Several specific factors relevant to the study of migrant women demand further exploration. The basic model in the economic migration literature is based upon the investments in host country specific human capital. The longer migrants reside in the host country, the more their investment in country-specific skills and hence the decrease in their initial disadvantage relative to natives (Hartog, 2005; Nekby, 2002; MacPherson and Stewart, 1989).

This model can be refined and extended by taking into account the role of the family in employment decisions. The so-called family investment hypothesis (FIH) states that labor market behavior of partnered migrant women must be understood in conjunction with how much her partner needs to invest in host country specific human capital (Long, 1980). The wife engages in paid work to finance family expenses, while the husband invests in necessary human capital. The findings for this hypothesis, however, are varied, with support only in the US and Canada (Duleep and Sanders, 1993; Baker and Benjamin, 1997). The hypothesis needs further specification, as investments will depend on other factors such as the transferability of human capital and educational level of both the husband and wife.

This economic rationale restricts our understanding of labor market behavior to individual or household choices based on human capital investments. Choices, however, are not made in a vacuum. Migration and integration policies of the host country may influence the need to invest in country specific skills. In addition, national work-family policies impact employment decisions when women enter parenthood (see e.g. Anxo et al, 2006; Uunk et al, 2003; Stier et al, 2001). 
Bevelander and Groeneveld (2006a) found differences in employment patterns in the Netherlands between migrant groups after controlling for human capital variables. The similarity between the employment pattern of Mediterranean and women in the country of origin was striking (OECD, 2002). This result points to the persistence of cultural norms, which are related to unequal gender roles. Specifically, gender role norms affect the allocation of time between home and paid work by women with the same human capital. They also affect education and fertility decisions, which in turn impact labor market opportunities and the value of family time, indirectly influencing the labor force participation among various ethnic groups (Reimers, 1985). This echoes Hakim's (2002) preference theory that describes how attitudes, values and life goals directly impact labor market outcomes. Using an OLS regression model on cross-sectional data, Groeneveld et al (2004) conclude that migrant women's views about women's roles are indeed related to their labor market participation.

In this study we focus on differences in labor force participation and in particular the hours worked in paid jobs between native and ethnic minority women. Besides that also other factors like various forms of discrimination, differences in gender role patterns, the relative income of the partner and various institutional factors may play a role, the main aim of this study is to analyze the effect of human capital and household factors on the hours worked by native and ethnic minority women. Like other studies, in this human capital framework, we expect that women with a higher general educational level have stronger incentives to work more hours in the labor market. This implies more opportunities for work as well as an increasing opportunity cost for staying at home. The presence of a spouse or partner can imply a lower or higher incentive to work or an increase or decrease in participating hours due to the relative income of the partner. This is highly connected to the presence of children that both can increase and decrease the number of hours worked by women. The latter is as well connected to the type of household the women is living in, more traditional with specialization of gender roles in household, or a more modern, based on splitting of non-market labor between genders. 


\section{$4 \quad$ Data and method}

Data for ethnic minority females come from the SPVA, the survey 'Social Position and Use of Facilities by Immigrants'. ${ }^{2}$ This survey studies the socio-economic and sociocultural position of the four largest ethnic minority groups in the Dutch society, namely: Turks, Moroccans, Surinamese and Antilleans/Arubans. As the migrant population lives geographically concentrated, the SPVA consists of random samples of the population in thirteen cities, including the four largest, in the Netherlands, resulting in a representative sample of the total population. Data for the native Dutch population come from the EBB, the labor force survey, of Statistics Netherlands (CBS).

In this study sub-samples of SPVA and EBB comprising the female population in the ages of 15 to 64 are pooled. Both first generation, those who actually migrated, and second generation, those who are born in the Netherlands but have at least one foreign born parent, are included in our sample. Table 2 gives an overview of the sub-samples used.

Table 2 Number of women in SPVA and EBB by ethnic group, 2002

\begin{tabular}{ll}
\hline Native Dutch & 33,379 \\
Turkish & 1,090 \\
Moroccan & 918 \\
Surinamese & 965 \\
Antillean & 696 \\
\hline Total & 37,048
\end{tabular}

Source: SPVA (ISEO/SCP) and EBB (CBS), 2002

This paper will study employment and hours worked of the aforementioned ethnic minority females compared to native Dutch females. Individuals are considered employed when they have specified in the questionnaire that they have employment 12

\footnotetext{
${ }^{2}$ Since 1988 the Institute for Sociological and Economic Research (ISEO) of the Erasmus University Rotterdam has held the SPVA-surveys every three or four years. In this paper we use the 1991, 1994, 1998 and in particular the 2002 edition. The 2002 edition was carried out by ISEO together with the Dutch Social and Cultural Planning Office (SCP) and - a particular part of it - the Dutch Interdisciplinary Demographic Institute (NIDI) (see for further details Groeneveld and Weijers-Martens, 2003).
} 
hours or more, unless otherwise is stated. Hours worked is based on actual hours worked instead of contract hours, as this is the only information available for native Dutch women.

Beside ethnic origin, generation and employment the variables age, marital status, number of children, year of arrival and the educational level will be adopted in the analysis. Marital status split between those who are in a partnership (married or cohabiting) and those who are not. The immigrant specific variable year of entering the Netherlands at a particular time gives us the possibility to infer something about the different cohorts of the particular ethnic group as well as it gives us the chance to study those who are born in the Netherlands and those who are not. We must be aware that the data for the second generation are highly right-censored. The second generation to a large extent contains young women who are observed only a short duration of their working lives (up to the age of 35). Educational level is measured by the highest level of graduation either in the Netherlands or in the country of origin.

We use a multinomial logit analysis to predict the probability of an individual to be in the following categories, working 1-11 hours, 12-34 hours, 35 or more hours or not being employed. Since we also include the possibility of not participating in the model we avoid the selection bias of the participation decision.

\section{$5 \quad$ Results}

\subsection{Employment and hours worked: descriptives}

In the following table (3) the change in employment rate for native Dutch and ethnic minority women is monitored. For all groups of women the employment rates have increased gradually since 1991. The highest percentage increase in employment is noted for the Moroccan women who show an increase of over 400 percent between 1991 and 2002 from the very low level of 6.2 to 26.3. Also a quarter of the Turkish women are employed twelve hours or more in 2002. Together these two groups show repeatedly the lowest employment rates relative to native Dutch and other ethnic minority women. Compared to the development of the native Dutch employment rate also Surinamese and Antillean women show a higher absolute increase in employment levels over time. 
Together, native Dutch and Surinamese women show the highest employment rate in 2002.

Table 3 Employment rate (at least 12 hours/week) of native Dutch and ethnic minority women, 1991, 1994, 1998 and 2002

\begin{tabular}{lllll}
\hline & 1991 & 1994 & 1998 & 2002 \\
\hline Native Dutch & 39.4 & 43.0 & 50.0 & 56.4 \\
Turkish & 15.6 & 17.3 & 21.2 & 26.4 \\
- First Generation & 16.1 & 15.6 & 19.7 & 23.9 \\
- Second Generation & 9.6 & 23.9 & 27.2 & 33.9 \\
Moroccan & 6.2 & 12.4 & 16.4 & 26.3 \\
- First Generation & 5.1 & 10.2 & 13.7 & 20.3 \\
- Second Generation & 16.1 & 22.6 & 24.9 & 41.4 \\
Surinamese & 34.2 & 41.5 & 55.1 & 56.2 \\
- First Generation & 34.9 & 43.0 & 54.3 & 61.0 \\
- Second Generation & 27.5 & 37.7 & 44.5 & 45.9 \\
Antillean & 25.9 & 39.4 & 44.0 & 49.7 \\
- First Generation & 25.3 & 34.1 & 42.3 & 50.5 \\
- Second Generation & 29.0 & 55.3 & 51.5 & 47.3 \\
\hline Source: SPVA, 1991, 1994,1998 and 2002 (ISEO/SCP), EBB, 1991 and 2002 (CBS) and Statline, 1994 \\
and 1998 (CBS)
\end{tabular}

For most of the ethnic minorities the second generation has higher rates than the first generation. This is in line with the idea that children of immigrants are exposed to the native country institutions from birth that would enhance integration in general and in the labor market. First generation Surinamese women, however, have a higher employment rate than the second generation. This first generation also shows higher employment rates than native Dutch women in the years 1994, 1998 and 2002. This observation can also be made for the first versus the second generation of Antillean women in 2002. When comparing generations we have to keep in mind though that the second generation to a large extent contains younger individuals still participating in education.

Earlier studies indicated a correlation between the increase of the employment level of women and the increase in part time jobs in the Dutch labor market in the 1990s (Batenburg et al. 2003; Euwals and Hogerbrugge, 2004). Apparent from table 4 is that all 
groups show an increase in shares part time employed and a decrease in full time employment between 1991 and 2002. This pattern is in line with earlier studies for native Dutch women and can be confirmed for ethnic minority women. The table also indicates that of all women that have some kind of employment, the share of full time workers among ethnic minority women is larger relative to native Dutch women.

Table 4 Share hours worked/week of all employed (at least 1 hour/week) by native Dutch and ethnic minority women, 1991 and 2002

\begin{tabular}{lcccc}
\hline & $1-11$ & $12-19$ & $20-34$ & $35+$ \\
\hline Native Dutch & 19.6 & 13.3 & 29.6 & 37.5 \\
-1991 & 16.1 & 16.1 & 40.3 & 27.6 \\
-2002 & & & & \\
Turkish & 9.6 & 6.6 & 23.4 & 60.5 \\
-1991 & 13.8 & 12.6 & 29.5 & 44.0 \\
- 2002 & & & & \\
Moroccan & 10.9 & 12.5 & 20.3 & 56.2 \\
-1991 & 15.4 & 16.2 & 33.5 & 34.9 \\
-2002 & & & & 55.7 \\
Surinamese & 6.9 & 8.2 & 29.2 & 43.0 \\
-1991 & 7.2 & 8.4 & 41.4 & 55.4 \\
-2002 & & & & 46.7 \\
Antillean & 7.8 & 9.0 & 27.7 & \\
-1991 & 9.0 & 10.5 & 33.7 & \\
- 2002 & & & & \\
\hline
\end{tabular}

Source: SPVA, 1991 and 2002 (ISEO/SCP) and EBB, 1991 and 2002 (CBS)

In previous studies we showed that the presence of children has a negative influence on the probability to be employed for all groups regardless their educational level. However, this effect of motherhood becomes smaller over time, again for both ethnic minority and native Dutch women. We concluded that over time more women successfully re-enter the labor market after becoming a mother (Bevelander \& Groeneveld, 2006a; 2006b). Table 5 illustrates this finding and gives the employment rates of native Dutch and ethnic minority women in 1991 and 2002 by number of children. 
Table 5 Employment rate (at least 12 hours/week) of native Dutch and ethnic minority women by number of children, 1991 and 2002

\begin{tabular}{|c|c|c|c|c|}
\hline & 0 children & 1 child & 2 children & 3 children or more \\
\hline \multicolumn{5}{|c|}{ Native Dutch } \\
\hline-1991 & 50 & 36 & 32 & 26 \\
\hline-2002 & 57 & 59 & 56 & 45 \\
\hline \multicolumn{5}{|c|}{ Turkish } \\
\hline - 1991 & 19 & 17 & 21 & 15 \\
\hline-2002 & 34 & 35 & 27 & 20 \\
\hline \multicolumn{5}{|c|}{ Moroccan } \\
\hline - 1991 & 11 & 14 & 4 & 2 \\
\hline-2002 & 44 & 40 & 32 & 16 \\
\hline \multicolumn{5}{|c|}{ Surinamese } \\
\hline - 1991 & 37 & 36 & 44 & 40 \\
\hline-2002 & 59 & 65 & 57 & 47 \\
\hline \multicolumn{5}{|c|}{ Antillean } \\
\hline-1991 & 32 & 38 & 25 & 21 \\
\hline-2002 & 59 & 62 & 39 & 38 \\
\hline
\end{tabular}

Source: SPVA, 1991 and 2002 (ISEO/SCP) and EBB, 1991 and 2002 (CBS).

Both mothers and women without children show increasing employment rates between 1991 and 2002. Compared to ethnic minority women and native Dutch mothers, native Dutch women without children only show a modest increase in employment level. In general, employment rates decrease with increasing numbers of children, as became apparent as well from the multivariate analysis conducted in Bevelander \& Groeneveld (2006a). For native Dutch women the difference in employment level of women with one child and women without children is especially high in 1991, suggesting that a considerable share of native women leave employment when they become a mother. In 2002, however, this fall in employment rate has disappeared.

As table 4 already showed, the increase in employment level can for a considerable part be attributed to an increase in part time jobs. This table also showed that of those in paid employment ethnic minority women are working more hours than native Dutch women. With our previous findings in mind, it is interesting to take a closer 
look at the average hours worked by women with and without children. Table 6 shows the results.

Table 6 Hours worked/week of those in paid employment (at least 12 hours/week), native Dutch and ethnic minority women by number of children, 1991 and 2002, means

\begin{tabular}{|c|c|c|c|c|}
\hline & 0 children & 1 child & 2 children & 3 children or more \\
\hline \multicolumn{5}{|c|}{ Native Dutch } \\
\hline-1991 & 34 & 29 & 28 & 29 \\
\hline-2002 & 31 & 25 & 23 & 23 \\
\hline \multicolumn{5}{|c|}{ Turkish } \\
\hline - 1991 & 36 & 34 & 33 & 31 \\
\hline-2002 & 33 & 32 & 30 & 31 \\
\hline \multicolumn{5}{|c|}{ Moroccan } \\
\hline - 1991 & 34 & 32 & - & - \\
\hline-2002 & 32 & 30 & 30 & 27 \\
\hline \multicolumn{5}{|c|}{ Surinamese } \\
\hline-1991 & 36 & 33 & 30 & 33 \\
\hline-2002 & 34 & 30 & 30 & 31 \\
\hline \multicolumn{5}{|c|}{ Antillean } \\
\hline-1991 & 35 & 34 & 28 & 32 \\
\hline-2002 & 33 & 32 & 33 & 28 \\
\hline
\end{tabular}

Source: SPVA, 1991 and 2002 (ISEO/SCP) and EBB, 1991 and 2002 (CBS)

For native Dutch women the difference in hours worked per week between mothers and women without children is remarkable. That is, in 2002, indicating that the increase in employment rate of mothers in the past ten years is an increase in part time jobs. Ethnic minority women only show a slight decrease in average amount of hours worked. In addition, the difference in hours worked between women with children and those without is relatively small. The difference in hours worked between native Dutch women and ethnic minority women is especially large for mothers in paid employment in 2002.

Summarizing the results form the descriptive tables in this section, we see observe that for both native and ethnic minority women labor market attachment increases between 1991 and 2002. Moreover, of those women who have obtained employment, 
native and ethnic minority women work a larger share in part-time jobs and less in fulltime jobs comparing 1991 with 2002. This result is in confirmation with the general increase of part-time jobs in the Dutch labor market in this period. Crude rates on employment rates by the number of children in the household confirm this picture and show that irrespective of the number of children the employment rate increases for all groups between 1991 and 2002 with native and Surinamese women having the highest levels followed by Antillean and Mediterranean women. Finally, a remarkable difference is visible when it comes to hours worked and presence of children. Irrespective of year, 1991 or 2002, ethnicity minority women work more hours than native women. Moreover, native women show instead a decrease in number of hours worked, especially when having one or more children between 1991 and 2002, which is not observed for ethnic minority women.

\subsection{Employment and hours worked: a multivariate analysis}

In the following (see table 7), we discuss the results of our multivariate analysis of employment and hours worked by native and ethnic minority women. In the analysis we include the following independent variables: age, age squared, educational level, years of residence, generation, marital status and children.

Table 7 Multinomial logit analysis with hours worked as a dependent variable (not working is reference category), odds ratios

\begin{tabular}{lcccc}
\hline & All & Native & Mediterranean & Caribbean \\
\hline Working 1-11 hours & & & & \\
Age & 1.008 & $0.973^{* *}$ & 0.995 & 0.958 \\
Age squared & $0.999^{* * *}$ & $1.000^{* *}$ & 0.999 & 1.000 \\
Native & Ref. Cat. & - & - & - \\
Turkey & $0.135^{* * *}$ & - & - & - \\
Morocco & $0.175^{* * *}$ & - & - & - \\
Suriname & $0.270^{* * *}$ & - & - & - \\
Dutch Antilles & $0.295^{* * *}$ & - & - & Ref. Cat. \\
No children & Ref. Cat. & Ref. Cat. & Ref. Cat. & 1.023 \\
One child & 1.043 & 1.043 & 1.015 & 0.905 \\
Two children & $1.194^{* * *}$ & $1.200^{* * *}$ & 1.930 & \\
\hline
\end{tabular}




\begin{tabular}{|c|c|c|c|c|}
\hline Three or more children & $1.131^{*}$ & 1.088 & 1.740 & 0.930 \\
\hline $\begin{array}{l}\text { Born in NL/Second } \\
\text { generation }\end{array}$ & Ref. Cat. & - & Ref. Cat. & Ref Cat. \\
\hline First generation & $0.644^{* *}$ & - & 1.075 & $0.346^{* * *}$ \\
\hline Single & Ref. Cat. & Ref. Cat. & Ref. Cat. & Ref. Cat. \\
\hline Married/Cohab. & $1.158^{* *}$ & $1.216^{* *}$ & 0.935 & 1.235 \\
\hline > $10 \mathrm{YSM}$ & Ref. Cat. & - & Ref. Cat. & Ref. Cat. \\
\hline$<10 \mathrm{YSM}$ & 0.820 & - & 0.573 & 1.126 \\
\hline Primary educ. & Ref. Cat & Ref. Cat. & Ref. Cat. & Ref. Cat. \\
\hline Low Secondary educ. & $1.546^{* * *}$ & $1.461 * * *$ & $1.989 * *$ & 1.351 \\
\hline High Secondary educ. & $1.700 * * *$ & $1.674 * * *$ & 1.569 & $2.173^{* * *}$ \\
\hline University educ. & $1.700^{* * *}$ & $1.695 * * *$ & 1.848 & 2.181 \\
\hline \multicolumn{5}{|l|}{ Working $12-34$ hours } \\
\hline Age & $1.417 * * *$ & $1.440 * * *$ & $1.204^{* * *}$ & $1.451^{* * *}$ \\
\hline Age squared & $0.995^{* * *}$ & $0.995 * * *$ & $0.997 * * *$ & $0.995 * * *$ \\
\hline Native & Ref. Cat. & - & - & - \\
\hline Turkey & $0.334 * * *$ & - & - & - \\
\hline Morocco & $0.412 * * *$ & - & - & - \\
\hline Suriname & $1.240^{*}$ & - & - & - \\
\hline Dutch Antilles & 0.819 & - & - & - \\
\hline No children & Ref. Cat. & Ref. Cat. & Ref. Cat. & Ref. Cat. \\
\hline One child & 0.962 & $0.914 * *$ & 1.338 & 1.035 \\
\hline Two children & $0.683^{* * *}$ & $0.626 * * *$ & 1.408 & 0.919 \\
\hline Three or more children & $0.440 * * *$ & $0.365 * * *$ & 0.786 & 0.873 \\
\hline $\begin{array}{l}\text { Born in NL/Second } \\
\text { generation }\end{array}$ & Ref. Cat. & - & Ref. Cat. & Ref. Cat. \\
\hline First generation & $0.814^{*}$ & - & 0.834 & 0.929 \\
\hline Single & Ref. Cat. & Ref. Cat. & Ref. Cat. & Ref. Cat. \\
\hline Married/Cohab. & 0.948 & 0.936 & $0.687 * *$ & $2.006 * * *$ \\
\hline > $10 \mathrm{YSM}$ & Ref. Cat. & Ref. Cat. & Ref. Cat. & Ref. Cat. \\
\hline$<10 \mathrm{YSM}$ & $0.569 * * *$ & & $0.474 * * *$ & $0.646 * *$ \\
\hline Primary educ. & Ref. Cat & Ref. Cat. & Ref. Cat. & Ref. Cat. \\
\hline Low Secondary educ. & $1.814^{* * *}$ & $1.702 * * *$ & $2.860 * * *$ & $1.347^{*}$ \\
\hline High Secondary educ. & $3.514^{* * *}$ & $3.321^{* * *}$ & $3.433 * * *$ & $3.418^{* * *}$ \\
\hline University educ. & $6.108 * * *$ & $5.915^{* * *}$ & $5.116^{* * *}$ & $5.213^{* * *}$ \\
\hline
\end{tabular}


Working 35+ hours

\begin{tabular}{|c|c|c|c|c|}
\hline Age & $1.494 * * *$ & $1.545^{* * *}$ & $1.336^{* * *}$ & $1.518^{* * *}$ \\
\hline Age squared & $0.994 * * *$ & $0.994 * * *$ & $0.996 * * *$ & $0.995^{* * *}$ \\
\hline Native & Ref. Cat. & - & - & - \\
\hline Turkey & 1.200 & - & - & - \\
\hline Morocco & $0.738 * *$ & - & - & - \\
\hline Suriname & $3.091 * * *$ & - & - & - \\
\hline Dutch Antilles & $1.754 * * *$ & - & - & - \\
\hline No children & Ref. Cat. & Ref. Cat. & Ref. Cat. & Ref. Cat. \\
\hline One child & $0.274^{* * *}$ & $0.245^{* * *}$ & 0.842 & $0.539 * * *$ \\
\hline Two children & $0.124 * * *$ & $0.102^{* * *}$ & $0.441^{* * *}$ & $0.404 * * *$ \\
\hline Three or more children & $0.109 * * *$ & $0.067 * * *$ & $0.358 * * *$ & $0.485 * * *$ \\
\hline $\begin{array}{l}\text { Born in NL/Second } \\
\text { generation }\end{array}$ & Ref. Cat. & - & Ref. Cat. & Ref. Cat. \\
\hline First generation & $1.259 * *$ & - & $0.629 * *$ & 1.022 \\
\hline Single & Ref. Cat. & Ref. Cat. & Ref. Cat. & Ref. Cat. \\
\hline Married/Cohab. & $0.458 * * *$ & $0.453^{* * *}$ & $0.701^{*}$ & 1.155 \\
\hline > $10 \mathrm{YSM}$ & Ref. Cat. & - & Ref. Cat. & Ref. Cat. \\
\hline$<10 \mathrm{YSM}$ & $0.354 * * *$ & - & $0.428 * * *$ & 0.591 \\
\hline Primary educ. & Ref. Cat & Ref. Cat. & Ref. Cat. & Ref. Cat. \\
\hline Low Secondary educ. & $1.900 * * *$ & $1.522 * * *$ & $2.755^{* * *}$ & $2.900 * * *$ \\
\hline High Secondary educ. & $3.815^{* * *}$ & $3.157 * * *$ & $3.441^{* * *}$ & $5.650 * * *$ \\
\hline University educ. & $9.176 * * *$ & $7.757 * * *$ & $6.301^{* * *}$ & $12.958^{* * *}$ \\
\hline Nagelkerke $\mathrm{R}^{2}$ & 0.445 & 0.380 & 0.249 & 0.329 \\
\hline
\end{tabular}

The model that includes both native and ethnic minority women shows that the chance to be working in a "small” job, less than 12 hours, relative to not working at all is lower for ethnic minority women relative to native women. For Turkish and Moroccan women this effect is also observed for 12-35 hour per week jobs. Only for Moroccan women we find a lower probability effect for working full-time, jobs of 35 and more hours per week, relative to native women. Surinamese women work less often in 1-11 hour jobs than native women, but participate more often in 12-25 hour or full time jobs. We see a significant difference between native and Antillean women when it comes to full time 
jobs: Antillean women work more often in full time jobs than native women and Surinamese women even more than Antillean women.

The above-mentioned differences between groups are not explained by differences in educational attainment or household characteristics between groups. These variables have an independent effect on the participation and hours worked by women. The educational level has a significant effect on the decision to participate as well as the number of hours worked. The higher the educational level, the higher the chance that women work and that they work more hours. In particular, higher educated women have a high probability of working full time. This result is in line with our expectations and according to the earlier theoretical proposition that women with a higher education have more to loose when not employed.

Women having two or more children have an increased probability to be working in a 1-11 hour job relative to not working at all and to be employed in jobs 12 hours or more. The odds to be employed full time are lower for women with children than for women without children. Least chance is found for those women with two or more children. These results are compatible with the previous results that women tend to combine having children and working a limited number of hours on the labor market and that having no children is connected with working in full time jobs.

To have a partner has a significant effect on the probability to obtain employment and on the number of hours worked. Women with a partner work more often in a "smaller" job than women without a partner. Moreover women with a partner work more seldom in full time jobs, regardless the number of children in the household. These results seem to point in the direction that women with a partner have a less strong incentive to work full time in the labor market and that gender equality has not been established in the Dutch labor market.

The impact of education and family characteristics on the probability to obtain employment and the number of hours worked for native, Mediterranean and Caribbean women separately is shown in columns 3-5 in table 7. A significant effect of education is measured on the decision to participate for native women. On top of that, the probability to work more hours increases with increased educational level. For Mediterranean and Caribbean women we see the same relation but the strengths of the effects are different. 
Increased educational level is related to a higher probability of working a higher number of hours. Mediterranean women have in particular a higher probability to work full time. Given the educational level, there is practically no difference in the probability to be employed or having a "small" job for Mediterranean women. Only Mediterranean women with lower secondary schooling have a higher probability to be employed in "small" jobs than Mediterranean women with primary schooling. The effect of education on full time employment is largest for Caribbean women. All in all, these results are in line with our earlier propositions.

The analysis shows large differences between groups concerning the influence of children on the labor market participation. Whereas for native women motherhood affects both the participation decision and the number of hours worked, for Mediterranean and Caribbean women this only affects the number of hours worked. Having two children does that native women work less often in 'small' jobs relative to not working compared to women without children. Native women with children work less often in larger part time and full time jobs than native women without children. In addition, the chance to obtain large jobs decreases with an increase in the number of children. This effect is particular strong for working full time. The effect of the number of children is only significant for the probability of working full time by Mediterranean and Caribbean women. The probability to obtain full time employment is lower when they have children and is independent of the number of children. Here we have to keep in mind that the sample for these ethnic groups is smaller than for native women and to some degree could explain the insignificant results. Summarizing these results gives us the interesting indication that native women with children have lower labor market attachment than women from the ethnic groups.

When it comes to the influence of having a partner on the participation decision and hours worked by women we observe large variation. Native women with a partner have more chance to have obtained a 'small' job than native women without a partner and a lower probability to be employed in full time jobs than native women with no partner. Mediterranean women with a partner less often work in larger part time jobs than Mediterranean women without partner. For Caribbean women we only find a strong effect of having a partner on the probability to be employed in a large part time job, i.e. 
working 12-34 hours a week and Caribbean women with a partner work more often in such a part time job than Caribbean women without a partner. When it comes to this variable, the pattern for native women is in line with earlier studies. The pattern for Mediterranean women seems to fit in this as well. Caribbean women on the other hand seem to be less affected in their labor market decision and how many hours to work by having a partner or not.

The influence of generation on the participation decision and hours worked is different for the two ethnic groups. First generation Caribbean women have a lower chance on a 'small' job relative to the second generation. First generation Mediterranean women have a lower probability to work full time than the second generation. Recent migration, less than 10 years in the country, has a significant negative effect on the hours worked. More than ten years residing in the Netherlands or to be born in the country shows to be connected to a higher chance of being employed in a larger part time or full time job. These results show that Mediterranean and Caribbean women have a different integration pattern. The - still relatively young - second generation Caribbean women work in smaller jobs and at the same time go for a higher educational level compared to the first generation. The Mediterranean second generation is showing a higher level of employment integration relative to the first generation.

\section{$6 \quad$ Conclusion and discussion}

In the context of the Netherlands the labor market integration and emancipation by ethnic minority women has more and more become the focus of both Dutch integration and emancipation policy. In relation to this, this paper deals with the labor market integration of native and ethnic minority women in the Netherlands. In particular the effects of the educational level and household characteristics on the participation decision of an individual and how many hours an individual works are analyzed.

Our results show some remarkable differences in employment patterns between native Dutch and ethnic minority women. Controlling for educational level, partnership and the presence of children, native Dutch women are working more often in part time jobs than Mediterranean and Caribbean women. For all women the educational level is an 
important determinant of employment and the number of hours worked. Whereas the number of children influences both the employment decision and the number of hours worked of native Dutch women, for Mediterranean and Caribbean women there is only an effect of the number of children on the odds of having a full time job. Both native and Mediterranean women are negatively affected by having a partner on the probability to have obtained full time jobs. For native women the probability to be employed in a small job of 1-11 hours increases with having a partner. Taken together, these results suggest us to formulate the following hypotheses.

From a household economics point of view the favorable educational level and the connected payment level for native Dutch women could explain the higher share of part time work compared to ethnic minority women. However, controlling for educational level our results indicate that native women are working more often in part time jobs than Caribbean women and Turkish women. On the other hand, payment level not only depends on the job and educational level, but also on the sector of employment.

Another explanation from this angle could be the relative income of the ethnic minority husband or partner. In both cases, to compensate and to increase the household income, the ethnic minority women have to increase the amount of working hours.

But also a cultural explanation could be given. The incidence of part time work among women is especially high in the Netherlands, which is often explained by gender role norms and accompanying institutional arrangements favoring the 1.5 breadwinner model. Whereas policy states that this should be the sum up of both partners working .75 in paid employment, Dutch practice shows that this is often a combination of the man working in a full time job and the wife in a part time job with the primary responsibility for the care of children. From this point of view differences in hours worked could be explained by gender role norms that affect the allocation of time between home and paid work by women with the same human capital. Following this kind of reasoning we suggest that ethnic minority women in paid employment can be conceived as a modern vanguard shedding an interesting new light on emancipation and integration policy in the Netherlands.

Our recommendations for future research are therefore in the same line and should include the type of work performed by native and ethnic minority women and the 
payment level of these jobs. Also, it should include the choice to work and how many hours and to what extent this is affected by the labor market characteristics of the partner. Furthermore, gender roles in family and domestic work, the labor market and society at large should be researched to a larger extent to see how this affect both work orientation and economic independency by women.

Finally, from a policy point of view, it is here proposed to evaluate the influence by various policies like the emancipation and integration policies by a comparative research design. An analysis of the same ethnic groups but in another context could be useful to shed some new light on differences in both various indicators of integration and emancipation of men and women of natives and various ethnic groups. 


\section{References}

Andersson, G. and K. Scott (2004). Labour-market attachment and entry into parenthood: the experience of immigrant women in Sweden. MPIDR Working paper WP 2004-011. Rostock: Max Planck Institute for Demographic Research.

Anxo, D., Cebrian, I., Fagan, C. and G. Moreno (2006). Patterns of labour market integration in Europe: a life course perspective. Anxo, D., Erhel, C. \& J. Schippers (eds.). Labour market transitions and time adjustment over the life course. Amsterdam: Dutch University Press.

Baker, M. and D. Benjamin (1997). The role of the Family in Immigrants’ Labor-market Activity: An evaluation of Alternative explanations. American Economic Review. vol. 87 (4). 705-727.

Batenburg, R., Asselberghs, K., Huijgen, F. and Meer P. van der (2003). De kwalitatieve structuur van de werkgelegenheid in Nederland. Deel V. 's Gravenhage: OSA (OSA-publicatie A196).

Becker, G.S. (1981). A treatise on the family. Cambridge: Harvard University Press.

Bevelander, P. (2000). Immigrant Employment Integration and Structural Change in Sweden, 1970-1995. Sodertalje: Almqvist \& Wiksell International.

Bevelander, P. (2005). The Employment Status of Immigrant Women: the case of Sweden. International Migration Review. vol. 39 (1).

Bevelander, P. and S. Groeneveld (2006a). Patterns of transition. Female native and ethnic minority employment patterns in the Dutch labour market, 1991 and 2002. Journal of Ethnic and Migration Studies. 32. 5. 785-807.

Bevelander, P. and S. Groeneveld (2006b). Female native and ethnic minority employment patterns in the Dutch labour market: transitions over time and over the life course. Anxo, D., Erhel, C. \& J. Schippers (eds.). Labour market transitions and time adjustment over the life course. Amsterdam: Dutch University Press

Blossfeld, H.-P. and J. Huinink (1991). Human Capital Investments or Norms of Role Transition? How Women's Schooling and Career Affect the Process of Family Formation. American Journal of Sociology. Vol. 97. 143-168. 
Budig, M.J. (2003). Are women's employment and fertility histories interdependent? An examination of causal order using event history analysis. Social Science Research. 32. 376-401.

Dingeldey, I. (2001). European Tax systems and their Impact on Family Employment Patterns. Journal of Social Policy. Vol. 30 (4). 653-672.

Duleep, H. O. and S. Sanders (1993). The Decision to Work by Married Immigrant Women. Industrial \& Labor Relations Review. vol. 46 (4). 677-690.

Euwals, R. and M. Hogerbrugge (2004). Explaining the growth of part time employment. Factors of supply and demand. Den Haag: СРB Netherlands Bureau for Economic Policy Analysis (CPB Discussion paper no. 31).

Groeneveld, S.M. and Y.M.R. Weijers-Martens (2003). Minderheden in beeld. De SPVA-02. [Ethnic minorities in the picture. The SPVA-survey 2002]. Rotterdam: Instituut voor Sociologisch-Economisch Onderzoek (ISEO).

Groeneveld, S., Marx, T. and A. Merens (2004). De arbeidsmarktpositie van vrouwen uit etnische minderheden. [The labour market position of ethnic minority women] In: Gijsberts, M. and A. Merens (red.). Emancipatie in estafette. De positie van vrouwen uit etnische minderheden. Den Haag: Sociaal en Cultureel Planbureau en Instituut voor Sociologisch-Economisch Onderzoek. 81-114.

Hakim, C. (2002). Life Style Preferences as Determinants of Women's Differentiated Labour Market Careers. Work \& Occupations. 29. 428-459.

Hartog, J. (2005). Immigrants in Europe: what do we know? University of Amsterdam/AIAS working paper.

Hooghiemstra, B.T.J. and J.G.F. Merens (1999). Variatie in Participatie. [Diversity in participation] Rijswijk: Sociaal en Cultureel Planbureau.

Kalmijn, M. and R. Luijkx (2003). Changes in Women's Employment and Occupational Mobility in the Netherlands between 1955 and 2000. GLOBALIFE Working paper no. 50. Bamberg: Faculty of Social and Economic Science. [To appear as chapter 4 in: Blossfeld, H-P. and H. Hofmeister (Eds.). Getting Ahead under Globalization: Mid-Career Women in Uncertain Times.]

Keuzenkamp, S. \& A. Merens (eds.) (2006). Sociale atlas van vrouwen uit etnische minderheden. Den Haag: Sociaal en Cultureel Planbureau. 
Long, J.E. (1980). The effect of Americanization on earnings: some evidence for women. Journal of Political Economy. 88. 620-629.

Lutz, H. (1994). The Tension between Ethnicity and Work: Immigrant Women in the Netherlands. Afshar, H. \& M. Maynard (eds.). The dynamics of 'Race' and Gender: Some Feminist Interventions. London: Taylor \& Francis. 182-195.

MacPherson, D. A. and Stewart, J. B. (1989). The Labor Force Participation and Earnings Profiles of Married Female Immigrants. Quarterly Review of Economics and Business. vol. 29 (3).

Nekby, L. (2002). How long does it take to integrate? Employment convergence of immigrants and natives in Sweden. Stockholm: Trade Union Institute for Economic Research (FIEF). FIEF Working paper series 2002, no. 185.

OECD (2002). Women at work: who are they and how are they faring? OECD. Employment outlook. Paris. 61-125.

Portegijs, W., Cloïn, M., Ooms, I. \& E. Eggink (2006). Hoe het werkt met kinderen. Moeders over kinderopvang en werk. Den Haag: Sociaal en Cultureel Planbureau.

Reimers, C.W. (1985). Cultural Differences in Labor Force Participation Among Married Women. American Economic Review. vol. 75 (2). 251-255.

Schoeni, R.F. (1998). Labor Market Outcomes of Immigrant Women in the United States: 1970 to 1990. International Migration Review. vol. 32 (2). 57-77.

Uunk, W., Kalmijn, M. and R. Muffels (2003). The impact of children on women's labor supply in Europe. A reassessment of the role of institutions. EPAG Working paper 2003-39. Colchester: University of Essex.

Stier, H., Lewin-Epstein, N. and M. Braun (2001). Welfare regimes, Family-supportive Policies, and Women's Employment along the Life-Course. American Journal of Sociology. 106. 1731-1760.

Van der Laan Bouma, W. and S. Groeneveld (2004). Vrouwen uit etnische minderheden: een demografisch profiel. In: Gijsberts, M. and A. Merens (red.). Emancipatie in estafette. De positie van vrouwen uit etnische minderheden. Den Haag: Sociaal en Cultureel Planbureau en Instituut voor Sociologisch-Economisch Onderzoek. 1330. 
Van Tubergen, F. and I. Maas (2004). Women migrants in the European Union. A demographic and socioeconomic profile. The Hague: Ministry of Social affairs and Employment.

Vlasblom, J.D. and J.J. Schippers (2005). Motherhood and labour market participation: generational dynamics. Paper presented at the TLM-NET conference Budapest, May 2005. 